\section{Sampling the lithosphere}

SIR-Two recent contributions to Nature ${ }^{1,2}$ highlight the importance of the continental lithospheric mantle to contemporary geochemistry. It is of interest both because it may represent a significant repository of incompatible trace elements that must be included in any model of the Earth's evolution, and because it contains old segments of the upper mantle, often with distinctive isotope ratios that are important tracers in studies of mantle geodynamics. As with all geochemical reservoirs, however, there is the fundamental problem of obtaining a representative sample, and this is particularly acute for the continental lithosphere.

Mantle xenoliths transported to the surface in alkali basalts and kimberlites remain the, least ambiguous. They have yielded much information on the mineralogy and composition of the uppermost mantle, but they are strikingly diverse. In particular, many of the garnet-bearing peridotites are unusually depleted in major elements, including iron, with the result that they are on average 1 per cent less dense than most mantle samples ${ }^{3}$. They also seem to be concentrated beneath the older cratonic areas, and to have the more extreme isotope ratios. By contrast, spinel-bearing peridotites occur in geologically young terrains, and both their isotope ratios and their majorelement compositions are probably similar to the uppermost mantle in oceanic areas. One inference is that lithosphere generating processes are no longer the same as they were in the Archaean, but whatever the causes, the diversity of mantle xenolith suites demands that a range of rock types be included in any estimate of lithosphere composition.

But are there other ways of sampling the lithosphere? Our understanding of the geochemical variations in the asthenosphere is dominated by the analysis of oceanic basalts which provide an average sample of the trace element and isotope characteristics of their source regions. Arguably a similar approach can be applied to the lithospheric sources of continental magmatism and although debates concerning the effects of crustal contamination continue, there is increasing confidence that many continental basalts are derived from mantle source regions that are both distinct from the asthenosphere and of similar age to the overlying crust. These observations are consistent with an origin within the continental lithospheric mantle, whereas variations in trace-element abundances imply that such sources can be stabilized by a variety of processes. These processes are as likely to occur at convergent plate margins ${ }^{4}$ as in extensional environments, contrary to the implication of Jochum et al. ${ }^{1}$ (more firmly stated by Sun and McDonough $^{5}$ ) that most of the lithospheric mantle is generated at divergent plate margin or intraplate tectonic regimes.

It is becoming increasingly clear that progress towards a fuller understanding of the subcontinental lithospheric mantle requires integration of the information derived from both xenoliths and basaltic magmas. The new analyses of spinel peridotites are most welcome and an important contribution to this goal. Considering their particularly fertile majorelement compositions and their traceelement similarity to oceanic basalts, they are, however, unlikely to be representative of the most distinctive features of the continental lithospheric mantle.

N. W. ROGERS

C. J. HAWKESWORTH D. S. ORMEROD P. D. KEMPTON

Department of Earth Sciences,

Open University,

Milton Keynes, MK7 6AA, UK

Jochum et al. reply-Rogers et al. suggest that the continental lithospheric mantle (CLM) may grow at convergent plate margins, although evidence for this process has not been found in spinel lherzolite xenoliths ${ }^{1}$. Their comments lead to two important questions in first, how representative are spinel lherzolite xenoliths of the CLM, particularly in older cratonic regions; and second, can continental basalts be used to characterize the composition of the CLM? We chose spinel peridotite xenoliths for this study because they are the freshest samples of continental lithospheric mantle available and therefore provide direct evidence on the lithospheric mantle's incompatible-traceelement composition. These xenoliths, unlike most garnet peridotites that are carried by kimberlitic magmas, have not been significantly affected by host contamination. The xenoliths we described cover a range of major and traceelement compositions. However, as Rogers et al. point out, they may not be representative of the continental lithospheric mantle in cratonic regions. Nevertheless, our conclusions ${ }^{1}$ concerning the growth and evolution of the CLM also hold when data for garnet peridotite xenoliths are considered ${ }^{6}$. Furthermore, comparisons of spinel and garnet peridotite suites show that they follow similar chemical trends.

Our arguments are not based on absolute abundances of major and/or incompatible trace elements, but on ratios of incompatible elements with similar degrees of incompatibility. We have noted that reliable data for some key element ratios such as niobium/thorium, niobium/lanthanum and strontium/neodymium are the same in strongly depleted and in fertile spinelbearing peridotite xenoliths, and this is also true for their garnet-bearing counterparts. These ratios are typical of midocean-ridge basalts and ocean island basalts, but distinct from those observed in island arc basalts ${ }^{1,5,6}$. So far no garnet- or spinel-bearing peridotite xenoliths have been reported to have the trace-element signatures resembling either those expected of convergent margin basalts and/or their residues. Thus, it is unlikely that significant volumes of the continental lithospheric mantle are developed at convergent plate margins.

Rogers et al. argue that the composition of continental basalts can be used to define the composition of the CLM, and that such data indicate CLM growth occurs at convergent plate margins. Other workers, however, continue to argue that many continental basalts may have been significantly affected by crustal contamination (see, for example, refs 5,7). This process would tend to obscure any information that they contain about their CLM source regions. In addition, although the geochemistry of continental basalts is determined partly by the CLM, the 'asthenosphere' is also involved ${ }^{8}$. In characterizing the composition of their source region, therefore, the effects of variable degrees of partial melting, crystal fractionation and the relative contributions of lithospheric and asthenospheric components must be taken into account. Some small-volume magmas (such as kimberlites and ultrapotassics) may be derived from CLM alone ${ }^{9}$, but they, and hence their sources, are volumetrically insignificant. Considering the many variables involved in basalt genesis, it seems unlikely that a unique and unambiguous composition of the continental lithospheric mantle can be deduced from basalt geochemistry. The comments of Rogers $e t$ al. highlight the critical need for more data on the chemistry of mantle xenolith.

W. F. McDONOUGH

Research School for Earth Sciences,

Australian National University,

Canberra, ACT 2601, Australia

K. P. JOCHUM H. PALME B. SPETTEL

Max-Planck-Institut für Chemie,

Saarstrasse 23, D-6500 Mainz, FRG

1. Jochum, K.P., McDonough, W.F., Palme, H. \& Spettel, B. Nature 340, 548-550 (1989)

2. Sun, S-S. Nature $\mathbf{3 4 0}, 509-510$ (1989)

3. Hawkesworth, C.J. et al. Earth planet. Sci. Lett. (submitted).

4. Ormerod, D.S. et al. Nature 333, 349-353 (1988)

5. Sun, S.-S. \& McDonough, W.F. Geol. Soc. Spec. Publ. 42 313-345 (1989)

6. McDonough, W.F. Earth planet. Sci. Lett. (submitted).

7. Hildreth, W. \& Moorbath, S. Contr. Miner. Petrol. 98, 455489 (1988).

8. McDonough, W.F. et al Geochim cosmochim Acta 49 2051-2067 (1985)

9. Nelson, D.R. et al. Geochim. cosmochim. Acta 50, 231 245 (1986). 